DOI 10.37882/2223-2982.2021.10-2.08

ПРОЦЕССЫ ТЕРМИНОЛОГИЗАЦИИ И ДЕТЕРМИНОЛОГИЗАЦИИ

\title{
В СОВРЕМЕННОМ СЛОВООБРАЗОВАНИИ НА ПРИМЕРЕ ОБЩЕМЕДИЦИНСКОЙ ЛЕКСИКИ В СМИ ПОСТКОВИДНОГО ПЕРИОДА
}

\section{TERMINOLOGICAL AND \\ DETERMINOLOGICAL PROCESSES \\ IN MODERN WORD FORMATION \\ AS EXEMPLIFIED BY GENERAL MEDICAL \\ VOCABULARY IN THE \\ POST-COLONIAL MEDIA \\ O. Gudkova \\ G. Khimich}

Summary: The article deals with the historical process of the concept of «term» formation, its modern understanding, as well as two productive phenomena in the XXI century: terminologization and determinologization. The study analyzes the headlines of the three most popular newspapers in 2021: Kommersant, Izvestia, Rossiyskaya Gazeta. The study makes it possible to conclude on the causes, mechanics and main trends of terminologization and determinologization in the sphere of medicine, which occurred in 2021 - after the coronavirus pandemic.

Keywords: term, terminologisation, determinologisation, word meaning, newspaper headlines, media language.

\section{BBEAEHИE}

И зменение в общественной и политической ситуации, «вызовы» времени и научно-технологический процесс постоянно привносят значительные изменения в наш язык, особенно это заметно в сфере инженерии, IT и медицины.

2020 год поставил нас перед лицом «чумы XXI века» - коронавирусной инфекции. Влияние ее распространилось на все сферы жизни. Язык как живая адаптируемая среда не мог не отреагировать на это явление. Как в научную, так и в общеупотребимую лексику начали проникать новые слова - данный факт определил АКТУАЛЬНОСТЬ НашеГо ИССЛЕДОВАНИЯ. АКТИвное УчастИе во внедрении и распространении вновь появившейся лексики принимают СМИ, ведь именно они подхватывают и транслируют все новые тенденции.

\section{ШЕАЬ ИССАЕАОВАНИЯ}

Доказать, что на возникновение новых лексем в
Гудкова Ольга Владимировна

старший преподаватель, Московский физико-технический институт (научный исследовательский университет), г. Москва gudkova.ov@mipt.ru

Химич Галина Александровна к.филол.н., доцент, Российский университет дружбы народов, г. Москва khimich-ga@rudn.ru

Аннотация: В статье рассматривается исторический процесс становление понятия «термин», его современное понимание, а также два продуктивных в XXI веке явления: терминологизация и детерминологизация. В исследовании произведен анализ заголовков трех наиболее популярных в 2021 году газет: «Коммерсант», «Известия», «Российской газеты». Исследование позволяет сделать вывод о причинах возникновения, механике и основных тенденциях терминологизации и детерминологизации в сфере медицины, произошедших в 2021 году - после коронавирусной пандемии.

Ключевые слова: термин, терминологизация, детерминологизация, значение слова, газетные заголовки, язык СМИ.

пласте общемедицинской лексики, фиксируемых в средствах массовой информации после периода коронавирусной инфекции, оказывают активное влияние процессы терминологизации и детерминологизации.

\section{ЗАААЧИ РАБОТЬ}

1. Рассмотреть историю зарождения понятия термин, его современное понимание, а также деривационные процессы в области терминологии, такие как терминологизация и детерминологизация.

2. Собрать и подвергнуть анализу фактический материал из СМИ, связанный с темой медицины.

3. Описать тенденции терминологизации и детерминологизаций XXI века на материале медицинской темы, сделать выводы о причинах их появления и сфере распространения, а также проанализировать сопутствующие процессы в сфере словообразования и словоупотребления.

\section{НАУЧНАЯ НОВИЗНА}

Постковидный период привнес в лексический состав 
практических всех языков новые реалии, новые лексемы, значения и сферы употребления слов, в том числе, основанных на явлениях терминологизации и детерминологизации. Изучение этого богатейшего материала представляется нам необходимым и весьма актуальным сегодня. На сегодняшний день это новый пласт научного исследования, освоение и описание которого представляется важным для понимания современных тенденций эволюции лексической системы языка.

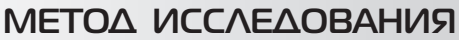

В работе использовались контекстуальный анализ, раскрывающий содержание и изменение смысловой структуры фразы и частично метод сплошной выборки.

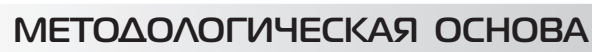

Методологической основой данного исследования послужили работы Виноградова В.В. по лексикологии и лексикографии [Виноградов, 1947], Вюстера Э. по общей терминологии и терминологической лексикографии [Вюстер, 1979], труд Лотте Д.С. «Основы построения научно-технических терминов: Вопросы теории и методики» [Лотте, 1961], а также исследования процессов терминологизации М.В.Косовой [Косова, 2004].

\section{История понятия термин}

Определение понятия термин сформировалось лишь в начале XX века. Основателями терминологии считаются Д.С. Лотте в СССР и Э. Вюстер в Австрии [Вюстер, 79, с. 43]. Основоположник Венской школы терминологии Вюстер (Wuster) утверждал, что в терминологии главенствует понятие, которое должно быть точно определено и не зависит от своего наименования. В лексикологии же, по его мнению, ключевое значение имеет языковое выражение. Поэтому традиционно терминологии говорят о понятиях, а лингвисты - о значениях.

Д.С. Лотте в работе «Основы построения научно-технических терминов: Вопросы теории и методики» писал, что терминология, особенно в части ее теоретических вопросов, является областью, примыкающей, с одной стороны, к технике и с другой, к лингвистике [Лотте, 1961, c. 12].

Сегодня трактовки «термина» разнятся. «Лингвистический энциклопедический словарь» дает следующее определение: «Термин (от лат. terminus - граница, предел) - слово или словосочетание, обозначающее понятие специальной области знания или деятельности» [Лингвистический энциклопедический словарь, 202, с. 508]. Логический словарь под редакцией Н.И. Кондакова называет термин «специальным словом или выражением, принятым для обозначения чего-нибудь в той или иной среде, профессии» [Логический словарь-справочник, 1975, с. 594]. Термин - точный носитель информации о научном понятии [Квитко, 1976, с. 19]. В.В. Виноградов пишет: «Слово исполняет номинативную или дефинитивную функцию, т. е. или является средством четкого обозначения, и тогда оно - простой знак, или средством логического определения, тогда оно - научный термин» [Виноградов, 1947, с. 12-13].

Интересны разработки, которые представил Juan C. SAGER в работе «A Practical Course in Terminology Processing, Amsterdam-Philadelphia, John Benjamins Publishing Company», [Sager, 1990, с. 1-12]. Автор перечисляет свойства идеального термина:

- термин должен относиться непосредственно к понятию, он должен выражать понятие ясно;

- термин не должен иметь синонимов;

- значение термина должно быть точным и не должно пересекаться по значению с другими терминами;

- значение термина не должно зависеть от контекста.

Подобная «идеальная» ситуация представляется практически невозможной в современном мире, если, конечно, мы не касаемся узкоспециальных областей, которые закрыты для рядового потребителя информации, такие как, например, физика плазмы, биомеханика и т.д.

\section{Терминологизашия и метерминологизашия в XXI веке: примеры}

Терминологизация - это процесс, при котором общеупотребимое слово получает новое терминологическое значении в конкретной области. О причинах, делающих возможным переход из общеупотребимого слова в термин пишет исследователь М.В. Косова: «Полифункциональность лексических единиц, возможность одним и тем же словом выразить сразу несколько значений служат определяющим фактором, лежащим в основе терминологической номинации» [Косова, 2004, с. 42].

В процессе же детерминологизации термин становится словом общей лексической системы. Проиллюстрируем для примера детерминологизацию слова «токсичность». Термин «токсичность» по версии Оксфордского словаря стал общеупотребимым словом 2018 года. В русском языке он используется также вне своего терминологического значения: «токсичные отношения», «токсичная маскулинность», «токсичный человек». Имеют ли современные значения что-то общее с оригиналом? Токсичность - это ядовитость; токсиометрический показатель вычисляется как величина, обратная средней смертельной дозе. Таким образом, общеупотребимое значение напрямую связано с терминологическим. В основном и устном корпусах «Национального корпуса русского языка» такие употребления не фиксируются. 
При этом поиск на сайте «Яндекс», используемый обычно для фиксации современного словоупотребления в живом языке, дает следующие результаты: 20811 запросов в месяц - «токсичные отношения», 5694 - «токсичная маскулинность» и 31543 - «токсичный человек». В то время, как термин «токсичность веществ» выдает всего 3143 запроса в месяц. Первоначально слово «токсичный» ассоциировалось с веществом, способным вызвать отравление (специальная лексика). Далее оно перешло в общеупотребимую лексику со значением «вредный», «вредоносный», «навязчивый».

Рассматривая функции термина, следует привести слова А.И. Моисеева: «Языковую функцию термина можно определить как назывную, номинативную: термины называют предметы, явления действительности и понятия о них. В этом, видимо, и состоит существо термина» [Татаринов, 1996, с. 138] В.А. Татаринов выделяет три основные функции термина: коммуникативную, когнитивную, номинативную. Наряду с основными функциями термина, Татаринов определяет также и дополнительные: структурно-языковые функции - функционирование термина в научном тексте; функции синонимии и вариантности; поведение термина в различных информационных каналах [Татаринов, 1996, с. 337]. Две последние, функции синонимии и вариантности, - поведение термина в различных информационных каналах - представляют для нас наибольший интерес.

\section{Изучение прошессов терминологизачии и Аетерминологизашии в области меАишины в СМИ в ситуашии коронавирусной пандемии 2021 года}

Технический прогресс, а также практически неограниченная доступность информации делают ранее узкоспециальную терминологию общеупотребимой. Такая «текучесть» способствует распространению терминов даже в бытовом языке. Личный опыт, например, в области медицины, вынуждает нас изучать и использовать термины, не только распространенные повсеместно (вирус, анамнез, лихорадка), но и редкие (скотома - ограниченный дефект поля зрения, не достигающий его границ; офтальмоскопия - метод осмотра внутренних оболочек глаза.).

Ведущую роль в переходе термина из специальной лексики в общеупотребимую играют СМИ. Терминологические понятия популяризуются средствами массовой информации, опираясь на актуальность темы в современном мире.

Медицинская терминология занимает особое место в лексической системе языка в силу стилистического, семантического и словообразовательного характера. Она отличается особенностями терминообразования и терминоупотребления. Область медицины вызывает живой интерес среди как профессионалов, так и обывателей не только своей актуальностью и востребованностью, но и большей степенью понимания и осознания терминологии. Так, например, термин «брахистохрона» - кривая, соединяющая две данные точки потенциального силового поля, двигаясь вдоль которой, материальная точка придёт из первой точки во вторую за кратчайшее время, - может быть узнан и осмыслен, наверное, только физиками и математиками. Если же мы упомянем такие термины, как «авитаминоз» - отсутствие витаминов - пищевых веществ, необходимых для поддержания жизненных функций, и связанные с этим нарушения; «мигрень»- заболевание, характеризующееся приступообразной, преимущественно односторонней, головной болью, которая сопровождается вегетативными нарушениями, - потребности в использовании специальных словарей не возникнет. Объясняется это, в том числе, и частотностью употребления каждого термина на телевидении, в художественной литературе и в СМИ. Обратим внимание на последние.

В нашем исследовании мы обратились к СМИ января 2021 года. Этот материал, по нашему мнению, должен был дать обширную почву для анализа новых явлений как терминологизации, так и детерминологизации в связи с тем, что во время распространения коронавирусной инфекции, впервые за многие десятилетия повлекшей за собой пандемию, в словарях практических языков мира в условиях новых реалий возникли не только новые лексемы, но и новые сферы употребления существующих слов, а также новые значения. Такой процесс трансформации лексического состава языков и стал для нас поводом для более детального научного изучения. Нами были отобраны три наиболее цитируемые в 2021 году газеты по версии портала «Медиалогия», занимающегося мониторингом СМИ и соцсетей: Коммерсант, Известия, Российская газета (далее РГ).

Результаты сбора материала из статей этих СМИ мы приводим в таблице. Мы отобрали статьи, напечатанные в январе 2021 года и содержащие в заголовках медицинскую тематику.

Нами были выбраны четыре критерия анализа заголовков, собранных из газет в указанный период:

1. Введение новых лексем, а также значений слов в обиход.

2. Терминологизация.

3. Детерминологизация.

4. Использование в заголовках скрытой цитации прецедентных текстов в сочетании с медицинской лексикой.

1. На основании анализа заголовков газет мы можем сделать вывод, что в общий обиход вошли следующие новые слова и словосочетания: коронавирус (ковид, 
Таблица 1.

Заголовки из газетных статей 11 - 29 января 2021 г.

\begin{tabular}{|c|c|c|c|}
\hline $\begin{array}{c}\text { Дата статей по теме } \\
\text { «Медицина» }\end{array}$ & Коммерсант & Известия & РГ \\
\hline \multirow[b]{2}{*}{ 11.01.21 } & 1 & 2 & 3 \\
\hline & $\begin{array}{c}\text { Коронавирус возвращается } \\
\text { сканикул }\end{array}$ & $\begin{array}{l}\text { Дальше - меньше: обойдет ли } \\
\text { Россию третья волна COVID - } 19\end{array}$ & $\begin{array}{c}\text { Вакцинация от ковида: новые } \\
\text { истории москвичей }\end{array}$ \\
\hline \multirow[b]{2}{*}{ 12.01.21 } & 4 & 5 & 6 \\
\hline & Краеукольный вопрос Европы & $\begin{array}{c}\text { Штаммовое предупреждение: } \\
\text { выявлен «российский» вариант } \\
\text { коронавируса }\end{array}$ & $\begin{array}{c}\text { После публикации в «РГ» } \\
\text { незрячая девочка прошла } \\
\text { обследование у лучших врачей }\end{array}$ \\
\hline \multirow[b]{2}{*}{ 13.01.21 } & 7 & 8 & 9 \\
\hline & $\begin{array}{c}\text { Снижение купательной } \\
\text { способности }\end{array}$ & $\begin{array}{c}\text { Ковидный билет: для чего } \\
\text { в мире создают сертификат } \\
\text { вакцинации }\end{array}$ & $\begin{array}{l}\text { В конце января в гражданский } \\
\text { оборот поступит более } \\
2 \text { миллионов доз вакцин }\end{array}$ \\
\hline \multirow[b]{2}{*}{ 14.01.21 } & 10 & 11 & 12 \\
\hline & Сиквенс подкрался незаметно & $\begin{array}{c}\text { Опасный сюрприз: в Буйнакске } \\
\text { отравились более } 70 \text { человек }\end{array}$ & $\begin{array}{c}\text { Собянин: Москва может } \\
\text { вернуться к нормальной } \\
\text { жизни в мае } \\
\end{array}$ \\
\hline \multirow[b]{2}{*}{ 15.01.21 } & 13 & 14 & 15 \\
\hline & Вирус уходит, но не прощается & $\begin{array}{c}\text { Одним мазком: диагностиро- } \\
\text { вать грипп и COVID - } 19 \text { будут } \\
\text { одновременно }\end{array}$ & $\begin{array}{c}\text { Голикова: массовая вакцина- } \\
\text { ция начнется } 18 \text { января }\end{array}$ \\
\hline \multirow[b]{2}{*}{ 16.01.21 } & 16 & 17 & 18 \\
\hline & Тесное показание & $\begin{array}{c}\text { Candida в убийцы: пандемия } \\
\text { может вызвать рост смертей } \\
\text { от грибков-мутантов }\end{array}$ & Маски не допустят срывов \\
\hline \multirow[b]{2}{*}{ 18.01.21 } & 19 & 20 & 21 \\
\hline & Иглы доброй воли & $\begin{array}{c}\text { Ковидные меры: как в России } \\
\text { стартовала массовая } \\
\text { вакцинация } \\
\end{array}$ & $\begin{array}{c}\text { Устала бояться: } \\
\text { репродуктивное здоровье }\end{array}$ \\
\hline \multirow[b]{2}{*}{ 19.01.21 } & 22 & 23 & 24 \\
\hline & Выгодное антитело & $\begin{array}{c}\text { Укол в спину: поставил ли Pfizer } \\
\text { под угрозу вакцинацию в ЕС }\end{array}$ & \\
\hline \multirow[b]{2}{*}{ 20.01.21 } & 25 & 26 & 27 \\
\hline & Скорая пишет, скорая знает & $\begin{array}{c}\text { Всем привет: чем различаются } \\
\text { «Спутник V», «ЭпиВакКорона» и } \\
\text { «КовиВак» }\end{array}$ & Корона не для мозга \\
\hline \multirow[b]{2}{*}{22.01 .21} & 28 & 29 & 30 \\
\hline & Нашла игла на камень & $\begin{array}{c}\text { Работа на поставки: как «Спут- } \\
\text { ник V» выходит на европейский } \\
\text { рынок }\end{array}$ & $\begin{array}{c}\text { Государство покроет } \\
\text { затраты на лекарства для } \\
\text { тяжелобольных детей }\end{array}$ \\
\hline \multirow[b]{2}{*}{23.01 .21} & 31 & 32 & 33 \\
\hline & Непривитым вход воспрещен & & $\begin{array}{c}\text { Голикова назвала } \\
\text { вредным внедрение } \\
\text { «ковидных паспортов» }\end{array}$ \\
\hline \multirow[b]{2}{*}{ 25.01.21 } & 34 & 35 & 36 \\
\hline & Ускорителем и термометром & $\begin{array}{c}\text { След COVID: анализ комнатной } \\
\text { пыли подскажет вспышки } \\
\text { эпидемии }\end{array}$ & $\begin{array}{c}\text { Однокомпонентная вакцина } \\
\text { «Спутник лайт» будет запущена } \\
\text { в феврале-марте }\end{array}$ \\
\hline \multirow[b]{2}{*}{26.01 .21} & 37 & 38 & 39 \\
\hline & У стоматологов зуб на рентген & $\begin{array}{c}\text { Ближе кДели: что даст рос- } \\
\text { сийской вакцине «прописка» } \\
\text { в Индии }\end{array}$ & \\
\hline
\end{tabular}




\begin{tabular}{|c|c|c|c|}
\hline $\begin{array}{c}\text { Дата статей по теме } \\
\text { «Медицина» }\end{array}$ & Коммерсант & Известия & РГ \\
\hline \multirow[b]{2}{*}{ 27.01.21 } & 40 & 41 & 42 \\
\hline & $\begin{array}{c}\text { Раковым больным назначают } \\
\text { местное лечение }\end{array}$ & $\begin{array}{c}\text { Сосудный день: дефицит вита- } \\
\text { мина К может приводить } \\
\text { к тяжелому COVID-19 }\end{array}$ & \\
\hline \multirow{2}{*}{28.01 .21} & 43 & 44 & 45 \\
\hline & Яйца поразил коронавирус & & Обезболивающие \\
\hline \multirow[b]{2}{*}{29.01 .21} & 46 & 47 & 48 \\
\hline & $\begin{array}{c}\text { Велика Россия, а уколоть } \\
\text { некого }\end{array}$ & $\begin{array}{c}\text { Снижение иммунитета длится } \\
\text { полтора-два месяца после } \\
\text { COVID - 19? }\end{array}$ & \\
\hline
\end{tabular}

COVID, корона), ковидный, сертификат вакцинации, антитело, «Pfizer», «Спутник V», «Спутник лайт», «ЭпиВакКорона» и «КовиВак», ковидный паспорт, масочный режим (примеры 1, 2, 3, 5, 8, 14, 22, 23, 26, 27, 33, 36).

2. Мы можем зафиксировать процесс терминологизации, то есть, использование общеупотребимым слов в значении терминов, в следующих случаях: корона, сертификат вакцинации, «Спутник V», «Спутник лайт», ковидный паспорт (примеры 2, 22, 26, 27, 33, 36).

Изучение ключевых и наиболее употребляемых слов в статьях позволяет составить следующий перечень устойчивых новых терминов:

- Коллективный иммунитет. Активное изучение эффекта началось в 1930-х годах в связи с эпидемией кори. 2020 год дал термину новую жизнь.

- Маршрутизация (больных). Термин появился в СМИ в 2014 году после появления Распоряжения от 2 апреля 2014 г. N 126-р о маршрутизации женщин, имеющих инфекционные заболевания в период беременности, родов и послеродовой период в Санкт-Петербурге. Открытие ковидных госпиталей в России в 2020 году поспособствовало частому употреблению термина в СМИ.

- Вакцина против COVID - 19. Вакцина, вызывающая формирование приобретённого иммунитета против коронавирусной инфекции COVID - 19, вызываемой коронавирусом SARS-CoV-2.

- QR - код. (англ. Quick Response Code - код быстрого реагирования; сокр. QR code) - тип матричных штрихкодов (или двумерных штрихкодов), изначально разработанных для автомобильной промышленности Японии. Первое использование - упаковки, плакаты, товары. Российские СМИ растиражировали термин во времена пандемии COVID - 19.

- Коронавирус. (лат. Coronaviridae) - семейство вирусов, включающее на май 2020 года 43 вида РНК-содержащих вирусов, объединённых в два подсемейства, которые поражают млекопитающих (включая человека), птиц и земноводных.
Название связано со строением вируса, шиповидные отростки которого напоминают солнечную корону. В прессе мы видим совершенно разное написание данного термина: коронавирус, ковид, COVID, корона, а также прилагательные, образованные от терминов: ковидный, коронавирусный. Журналисты непрофильных СМИ не придерживаются и устойчивого правила написания обоих терминов со строчной буквы.

3. Процесс детерминологизации можно увидеть в следующих примерах.

Интереснейшим, на наш взгляд, является путь, который проходит лексема «коронавирус» (и ее вариация «ковид»): от введения в общий обиход новой лексической единицы к детерминологизации. Как мы видим, как в СМИ, так и в обыденной речи, данная лексема все больше теряет связь с наукой и воспринимается уже не столько как термин, сколько приобретает обиходное значение, в которое вкладывается то синоним эпидемии, то угрозы, то оправдания невозможности реализации действия. Также нередки ее метафорические употребления, одно из которых мы видим в проанализированных газетных заголовках: «Коронавирус возвращается с каникул». В данном контексте коронавирус персонифицируется и предстает перед нами более как монстр или чудище. Другой пример: заголовок «Корона не для мозга». Тот же процесс наблюдается с прилагательным ковидный. Так, мы видим словосочетания «ковидный билет», «ковидные меры», «ковидный паспорт».

Среди заголовков есть и иные примеры детерминологизации: Сиквенс подкрался незаметно; Candida в убийцы: пандемия может вызвать рост смертей от грибков-мутантов; выгодное антитело и др. (примеры: 1, 8, $10,17,22,27,40)$.

4. При анализе заголовков на медицинскую тематику невозможно обойти стороной тему прецедентных высказываний, столь часто используемых сейчас в СМИ и дающих весьма интересные использования лексических 
единиц. Вызывает интерес различное использование данного ресурса языка разными газетами. Так «Коммерсант» и «Известия» для создания заголовков прибегают к приему прецедентных текстов и каламбура с применением парафраза («Скорая пишет, скорая знает», «Непривитым вход воспрещен»). В то время как «Российская газета» строит заголовки на фактической информации, т.е. объясняет содержание статьи и раскрывает тему самим заголовком, не используя каламбур («Голикова: массовая вакцинация начнется 18 января»). Примеры прецедентных высказываний мы нашли в заголовках 1, 2, 4, 5 , $7,10,13,14,16,17,18,19,22,23,25,28,31,34,38,41$, 46 (в тексте отмечены курсивом).

\section{ЗАКАЮЧЕНИЕ}

Таким образом, наше исследование показывает, что на возникновение новых лексем в пласте общемедицинской лексики, фиксируемых в средствах массовой информации после периода коронавирусной инфекции, оказывают активное влияние процессы терминологизации и детерминологизации. Терминологизация общеупотребительной лексики - процесс актуальный для современного русского языка. Основная тенденция - появление новых терминов в наиболее востребованных и актуальных в настоящее время сферах деятельности: это медицина, финансы, бизнес, торговля, компьютерные технологии и т.д. Кроме того, переход термина в общеупотребимую лексику - детерминологизация - также широко распространен. Специальная лексика активно используется не только в научно-технических контекстах, но и в языке современной публицистики, в частности, в газетных текстах, что определяет роль СМИ в «жизни» языка как существенную.

\section{ЛИТЕРАТУРА}

1. Sager, Juan C. A Practical Course in Terminology Processing, Amsterdam-Philadelphia, John Benjamins Publishing Company, 1990, UMIST, Manchester, 258 c.

2. Terentieva Ekaterina, Khimich Galina, Veselova Irina. The analysis of citation in headlines in the Spanish press // Cell Press, Heliyon, Volume 6, Issue 1, 2020. https://www.cell.com/heliyon/fulltext/S2405-8440(19)36814-8 https://doi.org/10.1016/j.heliyon.2019.e03155

3. Виноградов В.В. Лексикология и лексикография: М.: Изд-во Наука, 1947. 312 с.

4. Вюстер Э. Введение в общую терминологию и терминологическую лексикографию: Нью-Йорк, 1979. 215 с.

5. Квитко И.С. Термин в научном документе: Львов: Изд-во Высшая школа, 1976. 125 с.

6. Косова М.В. Терминологизация как лексико-семантический процесс // Вестник 0ГУ, 2004, 2, стр. 42 - 48.

7. Косова М.В. Терминологизация как процесс переосмысления русской общеупотребительной лексики: диссертация доктора филологических наук: 10.02.01. - Волгоград, 2004. - 403 с.

8. Лингвистический энциклопедический словарь / гл. ред. В.Н. Ярцева. - 2-е изд., доп. - М. : Большая рос. энцикл., 2002. - 709 с. Электронный ресурс: Термин (narod.ru)

9. Логический словарь-справочник, ред. Кондакова Н.И.: М.: Изд-во Наука, 1975. 721 .

10. Лотте Д.С. Основы построения научно-технических терминов: Вопросы теории и методики: М.: Изд-во АН СССР, 1961. 160 с.

11. Моисеев А.И. К определению термина в словарях: М.: Изд-во Наука, 1976. 12 с.

12. Национальный корпус русского языка. Электронный ресурс: https://ruscorpora.ru/new/corpora-structure.html

13. Татаринов В.А. Теория термина: История и современное состояние: М.: Изд-во Моск. лицей, 1996. 331 с.

( Гудкова Ольга Владимировна (gudkova.ov@mipt.ru), Химич Галина Александровна (khimich-ga@rudn.ru).

Журнал «Современная наука: актуальные проблемы теории и практики» 